\title{
RESEARCHING AND DEVELOPING WORK ACTIVITIES IN INFORMATION SYSTEMS: Experiences and the Way Forward
}

\author{
Mikko Korpela \\ University of Kuopio \\ Jonathan P. Allen \\ University of San Francisco \\ Olav Bertelsen \\ Aarhus University \\ Yvonne Dittrich \\ IT-University Copenhagen and \\ Blekinge Institute of Technology \\ Kari Kuutti \\ University of Oulu \\ Kristina Lauche \\ University of Aberdeen \\ Anja Mursu \\ University of Kuopio
}

The objective of this panel is to present and discuss different approaches to understanding and developing work practice that is facilitated by information systems. Such approaches are identified in research and practice in human-computer interaction, computer-supported cooperative work, human factors/ergonomics, developmental work research, and information systems, among others.

However, some of the approaches have remained purely academic while the more pragmatic approaches often lack a theoretical basis. The goal of this panel is to debate 
the potential and obstacles of various work-oriented approaches as practicable research methodologies as well as practicable requirements analysis and design methodologies in IS.

In trying to understand the role of theory in critical IS research, the concept of design artefacts has been valuable because it conveys a focus on how theories, methods, tools, etc., mediate design practice (Bertelsen 1998). A method in use is not the same as the method book; the fact that designers don't follow methods does not mean that the introduction of a method has no effect. A theory is a design artefact; misinterpreting a theory can be a step in achieving a good result. If designers don't have their own theory, theories imbedded in their tools may take over the designers' minds.

Activity theory (Engeström 1999), among other theories, has been a promising framework in IS for more than a decade; it is time to consider the practical packaging of the theory for design. Would stories, anecdotes, fairy tales, and some good examples be better ways to package the insights from activity theory informed workplace studies?

In German speaking countries, a different tradition of work-oriented research and practice has inspired systems developers (Frese and Zapf 1993). Is the Anglophone research community ready to learn from it?

Can pragmatic, design-oriented approaches like work system method (Alter 2001) and participatory design (Kensing and Blomberg 1998) be married with theoretically based approaches like activity theory? Can work-oriented IS approaches and workoriented software engineering approaches (Robertson and Robertson 1999) be linked together?

\section{REFERENCES}

Alter, S. "Which Life Cycle: Work System, Information System, or Software?," Communications of the AIS (7:17), 2001, pp. 1-53.

Bertelsen, O. W. Elements to a Theory of Design Artefacts: A Contribution to Critical Systems Development Research, Unpublished Ph.D. Thesis, Aarhus University, 1998.

Engeström, Y. "Activity Theory and Individual and Social Transformation," in Y. Engström, R. Miettinen, and R. Punamäki (Eds.), Perspectives on Activity Theory, Cambridge, UK: Cambridge University Press, 1999, pp. 19-38.

Frese, M., and Zapf, D. "Action as the Core of Work Psychology: A German Approach," in H. C. Triandis, M. D. Dunnette, and L. M. Hough (Eds.), Handbook of Industrial and Organizational Psychology (2 $2^{\text {nd }}$ ed., Vol. 4), Palo Alto, CA: Consulting Psychologists Press, 1993, pp. 271-340.

Kensing, F., and Blomberg, J. "Participatory Design: Issues and Concerns," Computer Supported Cooperative Work (7:3-4), 1998, pp. 167-185.

Robertson, S., and Robertson, R. Mastering the Requirements Process, Reading, MA: AddisonWesley, 1999. 